\title{
INFLUENCE OF INTERFACIAL TRANSITION ZONE ON ENGINEERING PROPERTIES OF THE CONCRETE MANUFACTURED WITH RECYCLED CERAMIC AGGREGATE
}

\author{
César MEDINA ${ }^{\mathrm{a}}$, Wenzhong ZHU $^{\mathrm{b}}$, Torsten HOWIND ${ }^{\mathrm{b}}$, \\ María Isabel SÁNCHEZ DE ROJAS ${ }^{a}$, Moisés FRÍAS ${ }^{a}$ \\ a "Eduardo Torroja" Institute for Construction Sciences, C/Serrano Galvache, 4, 28033, Madrid, Spain \\ ${ }^{b}$ School of Engineering, University of the West of Scotland, Paisley campus, Paisley, PA1 2BE, United Kingdom
}

Received 24 May 2012; accepted 24 Oct 2012

\begin{abstract}
The influence of the local micro-properties of the interfacial transition zone (ITZ) on macro-properties on the behaviour concretes is studied for recycled concretes made with $20 \%$ and $25 \%$ recycled ceramic aggregate from sanitary ware waste. This study carried out using nanoindentation and SEM technique aims to explore interface thickness and variations in its elastic modulus. The results show that the minimum and mean values of the elastic modulus and the ITZ thickness impact concrete mechanical and elastic properties to different degrees. Finally, that nanoindentation provides an indispensable tool for studying and assessing the effect of new materials (e.g. recycled aggregates) on the micromechanical properties of the interfacial transition zone (ITZ) and its effect on engineering properties (compressive and splitting tensile strength and modulus of elasticity) of these new concretes.
\end{abstract}

Keywords: interfacial transition zone, recycled ceramic concrete, compressive and splitting tensile strength, modulus of elasticity.

\section{Introduction}

The industrial and economic growth observed in more economically developed countries in recent years has brought with it a considerable increase in the generation of wastes. Sustainability performance of the society is an indispensable aspect in attaining the goal of sustainable development (Shen et al. 2007). Nowadays, there are intensive investigations carried out in order to utilize the different wastes (construction and demolition wastes, ceramic materials, asphalt, tyres, etc.) in the manufacture of new cements and concretes (Mačiulaitis et al. 2009; Kavussi et al. 2011).

Concrete is usually considered as a heterogeneous material consisting of three main phases: aggregates, cement paste and the interfacial transition zone (ITZ) between aggregate/paste. All concrete properties are related to the characteristics of these three phases. In particular, an understanding of the inter-relationships between concrete composition, structure and properties depends largely on the knowledge of both the paste and the paste/ aggregate interface.

Aggregate/paste, steel/paste and fibre/paste interfacial transition zones have been studied since the 1950's by a number of research teams (Monteiro et al. 1985; Ollivier et al. 1995; Paulon et al. 2004), who explored the microstructure and properties of the ITZ under the influence of different factors, such as w/c ratio, age, type of aggregate and the presence or different admixtures. Their findings revealed that characteristics of ITZ often differ from those of the bulk cement paste, due primarily to microstructural differences (van Breugel et al. 2004): e.g. with greater porosity, less unhydrated clinker phases, precipitation of large portlandite crystals that tend to be aligned perpendicularly to the aggregate surface and the presence of more ettringite. These differences are usually explained by the origin of the ITZ (Wang et al. 2009) which includes: a) the so called "wall" effect that prevents dense packing of cement grains against the relatively flat aggregate surface or fibre, or steel surface; and b) the microbleeding effect that leads to accumulation of water underneath the coarse aggregate particles or the steel bars and the flocculation effect of the small cement grains.

The extent of practical impact of these microstructural differences between the ITZ and the bulk paste on the properties of concrete has been debated (Bentur et al. 2000; Wang et al. 2009) appeared to suggest that such differences of the ITZ did not have significant impact on concrete properties and they were of academic interest only. Whereas other researchers (Akcaoglu et al. 2005; 
Akçaoğlu et al. 2004; Lee, Park 2008) claimed that since the interfacial transition zone is the weakest part of the microstructural system and the place where cracks first appear, it plays a significant role on the mechanical and transport properties of concrete. However, it was argued (Diamond, Huang 2001) that even for concrete with a $\mathrm{w} / \mathrm{c}$ ratio of 0.50 , the ITZ structure need not be assumed to have an adverse effect on permeability or strength. Two committees set up by RILEM to study the topic concluded (Bentur et al. 2000) that ITZ properties may have a moderate but certainly not a drastic effect on concrete strength or durability.

The traditional procedures (SEM, BSE, ESEM, TEM and microhardness) for studying cement paste, mortar and concrete microstructure have been supplemented in the last 15 years by nanoindentation (Davydov et al. 2011; Stark 2011; Zhu et al. 2004a). This technique, has been used to determine the micro-mechanical properties of different phases in hydrated cement (Velez et al. 2001), cement paste itself (Hughes, Trtik 2004; Mondal et al. 2007; Zhu et al. 2007) and the ITZ, aiming to better correlate structure and mechanical properties at the microscale to the macro-mechanical behaviour of these materials.

A number of researches have applied nanoindentation to study the micro-mechanical properties of the ITZ in fibre/paste (Lee et al. 2009; Sakulich, Li 2011; Sorelli et al. 2008; Wang et al. 2009; Zhu, Bartos 1997), steel/paste (Zhu et al. 2004b; Zhu, Bartos 2000; 2005) or natural aggregate/paste systems (Mondal et al. 2009; Trtik, Bartos 1999). By contrast, no published report was found on research conducted to analyse the variation in the micro-properties of the ITZ in recycled aggregate/ paste system, when recycled aggregates were used to replace natural aggregate in normal concrete mixes. With an increasing emphasis on sustainability by using recycled aggregates in concrete, it is important to understand the nature and properties of the ITZ and its impact on concrete properties for such mixes.

The focus of the present paper is on the ITZ between recycled produced from sanitary ware industrial waste, and cement paste, in concrete mixes with $20 \%$ and $25 \%$ of the natural aggregate replaced by recycled aggregate. More specifically, it is to explore the thickness of the different ITZs identified (i.e. with the glazed side and ceramic side of the recycled aggregate, as well as with the natural aggregate) and the variations in elastic modulus. The effect of this new aggregate on local micro-properties in the ITZ is quantified and its impact on the engineering properties of concrete is discussed.

\section{Materials and methods}

\subsection{Materials}

The natural aggregate employed can be sub-divided into two categories: the coarse fraction (gravel) of $4 / 20 \mathrm{~mm}$ in size, and the fine fraction (sand), with grains of less than $4 \mathrm{~mm}$ in size. The main component, $\mathrm{SiO}_{2}$, accounted for $97 \%$ wt. of these aggregates, which also contained $\mathrm{Al}_{2} \mathrm{O}_{3}$ and $\mathrm{Fe}_{2} \mathrm{O}_{3}$ as minority oxides. Their mineralogical composition was dominated by quartz, followed to a lesser extent by another series of aluminosilicates belonging to the mica and feldspar groups.

The recycled aggregate employed came from a ceramic sanitary ware factory. This waste was crushed with a jaw crusher and then sieved to obtain the $4 / 12.5 \mathrm{~mm}$ fraction. There are two visually distinguishable sides in the recycled aggregate as shown in Figure 1: the glazed side that formed the external surface of the original sanitary ware, and the ceramic side that corresponded to the internal part of the sanitary ware products.

The physical and mechanical properties of the natural and recycled aggregates are shown in Table 1 (Medina et al. 2011) which comply with the requisites established in standard EN 12620 (CEN. 2009b) and Spanish Code Structural Concrete (EHE-08) (Comisión Permanente del Hormigón 2008).

The chemical composition of this ceramic waste was similar to that of other ceramic materials used in construction sector (tiles, bricks, etc.) (Sánchez de Rojas et al. 2001, 2003, 2006, 2007). The internal part was composed mainly of $\mathrm{SiO}_{2}, \mathrm{Al}_{2} \mathrm{O}_{3}$ and $\mathrm{Fe}_{2} \mathrm{O}_{3}$, which

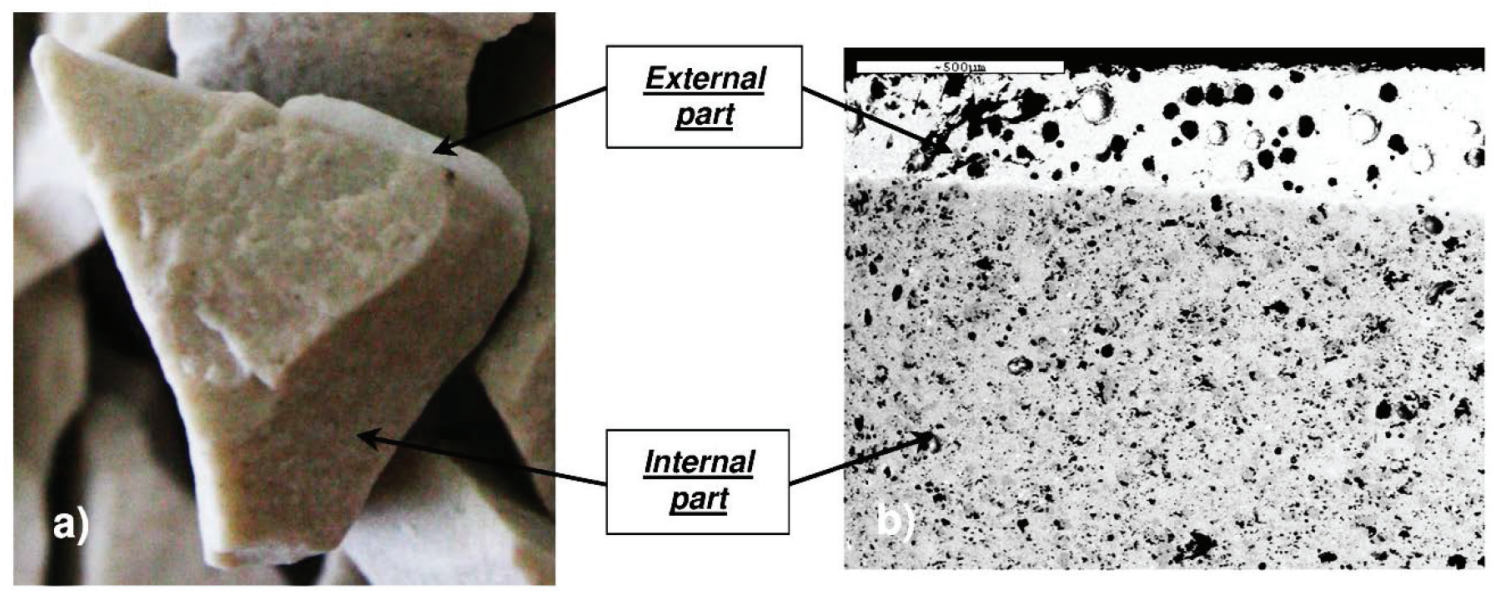

Fig. 1. Recycled ceramic aggregate: a) General aspect; b) BSE image $(\times 75)$ 
Table 1. Physical and mechanical properties of coarse aggregates

\begin{tabular}{lcc}
\hline Characteristic & Gravel & Ceramic \\
\hline Dry sample real density $\left(\mathrm{kg} / \mathrm{dm}^{3}\right)$ & 2.63 & 2.39 \\
\hline Water absorption (wt. \%) & 0.23 & 0.55 \\
\hline Flakiness Index (wt. \%) & 3 & 23 \\
\hline "Los Ángeles" coefficient (wt. \%) & 33 & 20 \\
\hline Total porosity (vol. \%) & 0.23 & 0.32 \\
\hline
\end{tabular}

constituted $93.81 \%$ of the total, whilst in the external part the proportion of the previous components dropped to $68.24 \%$, with zircon $\left(\mathrm{ZrO}_{2}\right)$ representing $12.62 \%$ and calcium oxide $(\mathrm{CaO})$ comprising $11.80 \%$. Meanwhile, the alkalis $\left(\mathrm{MgO}, \mathrm{NaO}\right.$ and $\left.\mathrm{K}_{2} \mathrm{O}\right)$ formed minority components in both parts.

A BRUKER Theta-Theta D8 Advance diffractometer fitted with a $2.2 \mathrm{~kW} \mathrm{Cu}$ anode but no monochromator was used to determine the mineralogical composition of the materials. The main crystalline components found in the ceramic waste were quartz, orthoclase, mullite, hematite, and zircon (Medina et al. 2011).

The cement used for mixing the concretes was CEM I 52.5 R type Portland cement in accordance with European standard EN 197-1 (CEN 2011), with content in clinker greater or equal to $95 \%$, and with $5 \%$ additional components.

\subsection{Concrete mixes used}

Three types of concretes were prepared: a reference concrete (RC) and two concretes (CC20 and CC25) in which 20 or $25 \%$ wt. of recycled aggregate was used in place of natural coarse aggregate.

The concrete was mixed and cured as specified in European standard EN 12390-2 (CEN 2009a) and used to make test specimens measuring $\varnothing 150 \mathrm{~mm} \times 300 \mathrm{~mm}$ and $150 \times 150 \times 150 \mathrm{~mm}$ for determining the mechanical and ITZ properties, respectively. The design and calculation of these mixes was carried out using the "De La Peña" method (Fernández 2007). Details of the mixes and physical properties (consistency and bulk density) of the concretes are given in Table 2 and Table 3, respectively.

The modulus of elasticity of the concretes has been calculated through an empirical formula recommended by ACI 318-08 (ACI Comittee 318 2008) that it suggests this properties of concrete function of its compressive strength and density Eqn (1):

$$
E c=0.043 w_{c}^{1.5} \sqrt{f_{c k}}
$$

where: $w_{c}\left(\mathrm{~kg} / \mathrm{m}^{3}\right), f_{c k}(\mathrm{MPa})$ y $E c(\mathrm{MPa})$ are 28 days density, compressive strength and modulus of elasticity of concrete, respectively.

\subsection{Sample preparation for nanoindentation test}

The reliability of results obtained from nanoindentation highly depends on the surface quality of the sample to
Table 2. Details of the concrete mixed used

\begin{tabular}{lccc}
\hline $\begin{array}{l}\text { Mix proportion } \\
\left(\mathrm{kg} / \mathrm{m}^{3}\right)\end{array}$ & RC & CC-20 & CC-25 \\
\hline Sand & 716.51 & 725.81 & 728.14 \\
\hline Gravel & 1115.82 & 892.66 & 836.87 \\
\hline Ceramic & 0.00 & 216.43 & 270.53 \\
\hline Cement & 398.52 & 387.64 & 384.91 \\
\hline Water & 205.00 & 205.00 & 205.00 \\
\hline
\end{tabular}

Table 3. Physical properties of the concrete

\begin{tabular}{lccc}
\hline Physical properties & RC & CC-20 & CC-25 \\
\hline Slump $(\mathrm{mm})$ & 75 & 72 & 71 \\
\hline Density $\left(\mathrm{kg} / \mathrm{m}^{3}\right)$ & 2390 & 2360 & 2370 \\
\hline
\end{tabular}

be tested. Thus sample preparation (ASTM 2007; Sorelli et al. 2008; Wang et al. 2009) is a very important part of the nanoindentation studies on cementitious materials. The heterogeneity of the material with its wide variation in the mechanical performance $(E=0 \mathrm{GPa}$ for pores up to $E>100 \mathrm{GPa}$ for unhydrated cement clinker grains and aggregates) demands a complex sample preparation procedure.

Due to low indentation depth only extremely smooth and flat surfaces allow to obtain reliable and representative test results.

After 28 days curing in a water tank, the centre piece of the $150 \times 150 \times 150 \mathrm{~mm}^{3}$ cubes was extracted using a diamond saw. This was later cut into small samples of the size about $15 \times 15 \times 10 \mathrm{~mm}^{3}$. For the further preparation the specimens were embedded in resin disks $(\varnothing 30 \mathrm{~mm})$ followed by a vacuum impregnation with an epoxy resin with an elastic modulus of around $3 \mathrm{GPa}$. The resin impregnation was required to support and prevent the loss of the weaker phases in the ITZ and the cement paste during the specimen preparation. To obtain the final test specimens for nanoindentation subsequent grinding and polishing were performed, finishing the polishing steps with a $1 / 4 \mu \mathrm{m}$ diamond particle sprays. Throughout the preparation process only alcohol or oil-based polishing sprays and lubricants were used to avoid further cement hydration and possible dissolution of hydrate phases.

\subsection{Nanoindentation testing}

Nanoindentation is used by many researches in the world to determine micro-mechanical properties of various materials. Nevertheless, we recall briefly the operational principles of nanoindentation. It is making contact between a sample with mechanical properties to be determined and an indenter tip of known geometry and mechanical properties. When in contact an increasing load is applied to the indenter causing the penetration of the indenter tip into the investigated surface. After reaching a predefined maximum load and typically a short hold period at this value the load is withdrawn 


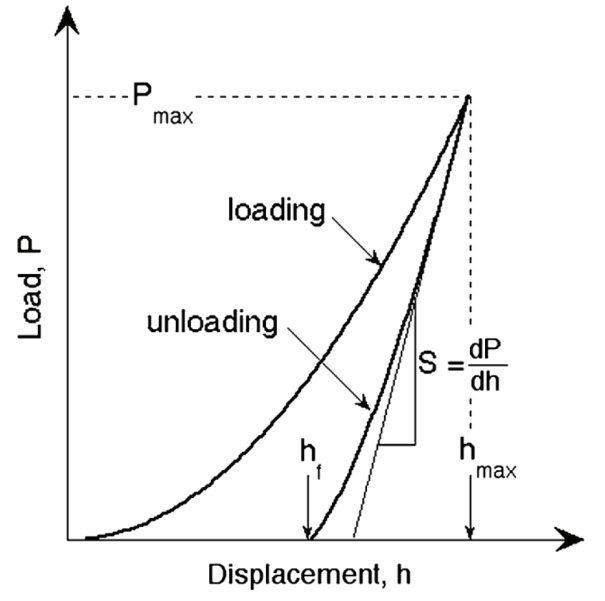

Fig. 2. Theoretical indentation load $v$ displacement curve

and the penetration depth decreases due to the elastic recovery of the deformed material (Zhu et al. 2007; Zhu, Bartos 2000). The change in load $(P)$ and depth $(h)$ is continuously recorded over the duration of the experiment. A typical outcome (Oliver, Pharr 2004) of nanoindentation testing is an indentation loaddisplacement (depth) hysteresis curve such as shown in Figure 2.

The determination of the elastic recovery by analysing the unloading data according to a model for the elastic contact problem enables to calculate the modulus of elasticity $(E)$. Details of the theoretical background and methodology for the elastic modulus determination have been reviewed and discussed by Oliver and Pharr (Oliver, Pharr 2004) leading to the following Eqns (2) and (3) (Zhu et al. 2004b):

$$
\begin{gathered}
S=\frac{d P}{d h}=\frac{2}{\sqrt{\pi}} E_{r} \sqrt{A} ; \\
\frac{1}{E_{r}}=\frac{\left(1-v^{2}\right)}{E}+\frac{\left(1-v_{i}^{2}\right)}{E_{i}},
\end{gathered}
$$

where: $S=d P / d h$, is the slope of the upper portion of the unloading curve during the initial stages of unloading (also called contact stiffness). In Eqns (2) and (3) $E_{r}$ stands for the reduced elastic modulus and $A$ is the projected contact area of the indenter tip and. $E$ is Young's modulus and $v$ is Poisson's ratio of the tested materials.

Finally, $E_{i}$ and $v_{i}$ represent the material parameter of the indenter tip (e.g. diamond, $E_{i}=1141 \mathrm{GPa}$ and $\left.v_{i}=0.07\right)$.

The nanoindentation experiments in this study were performed using an Agilent G200 Nano Indenter ${ }^{\circledR}$ fitted with a Berkovich indenter tip.

To study the ITZ properties, grids of indentation testing points with varying distances to the actual aggregate-paste interface were selected. The spacing between the indentation test points used were usually $10 \mu \mathrm{m}$ or $20 \mu \mathrm{m}$ to cover a sufficient area and also to avoid possible overlapping of the test areas. Nanoindentation testing with a maximum load of $2 \mathrm{mN}$ (corresponding to an average indentation depth of $300 \mathrm{~nm}$

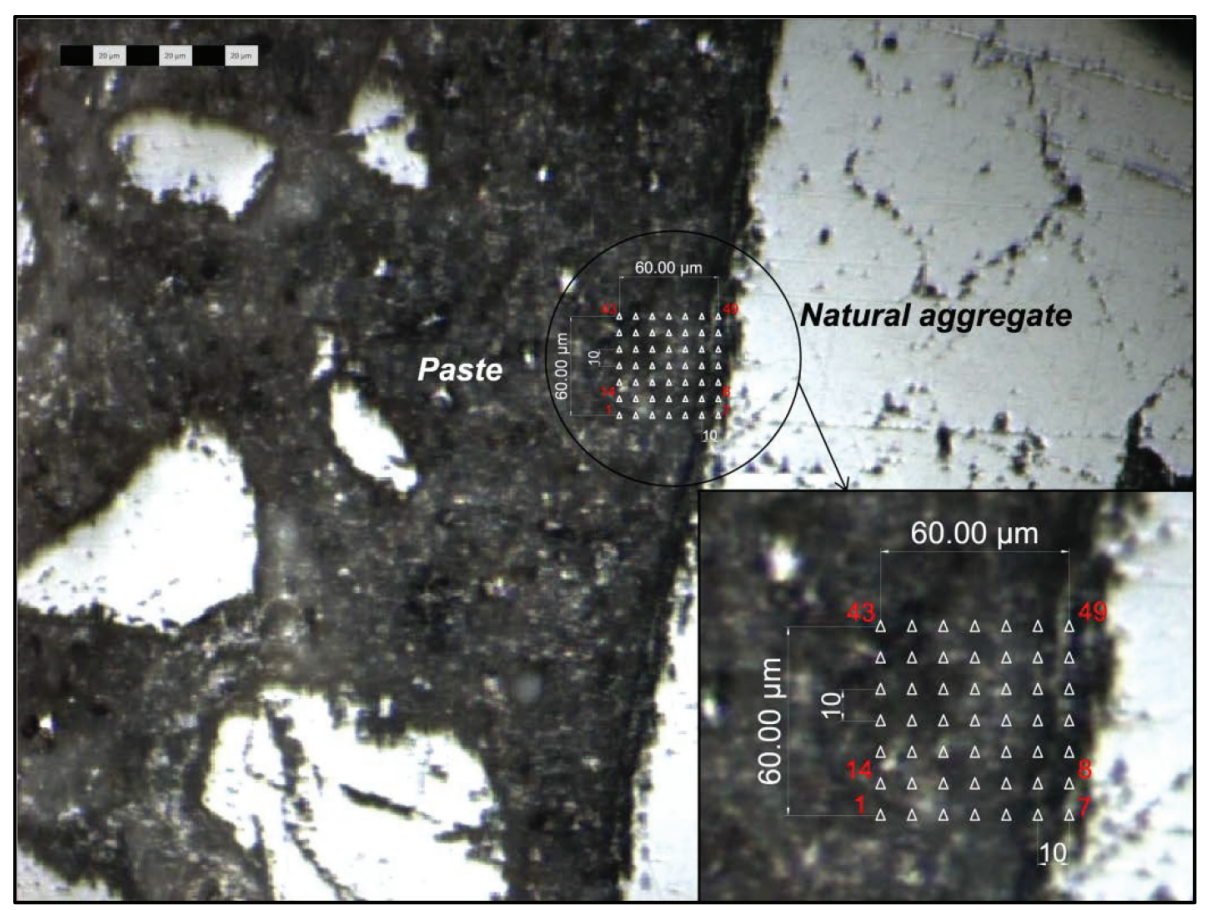

Fig. 3. BSE image of natural aggregate interfacial transition zone, where the dimension of the indented area is $60 \times 60 \mu \mathrm{m}$ with an indent spacing of $10 \mu \mathrm{m}$ 
in most cases) was carried out at each grid points. The perpendicular distance of each indentation point to the actual aggregate - paste interface was measured using an image analysing and the AutoCAD ${ }^{\circledR} 2012$ tool (Figs 3-5).

Some selected indentation areas are shown in the BSE images of the ITZ between aggregates/paste in Figures $3-5$. The indentation areas are contained within the rectangles outlined in the figures; the number, which always begins from 1, refers to the sequence of the indentation tests carried out in each chosen indented area, which facilitate the measurement of the distance to ITZ for each test point.

Validation of test results after the indentation testing was performed for each point to identify abnormal or discontinuous indentation test curves shapes, high sur-

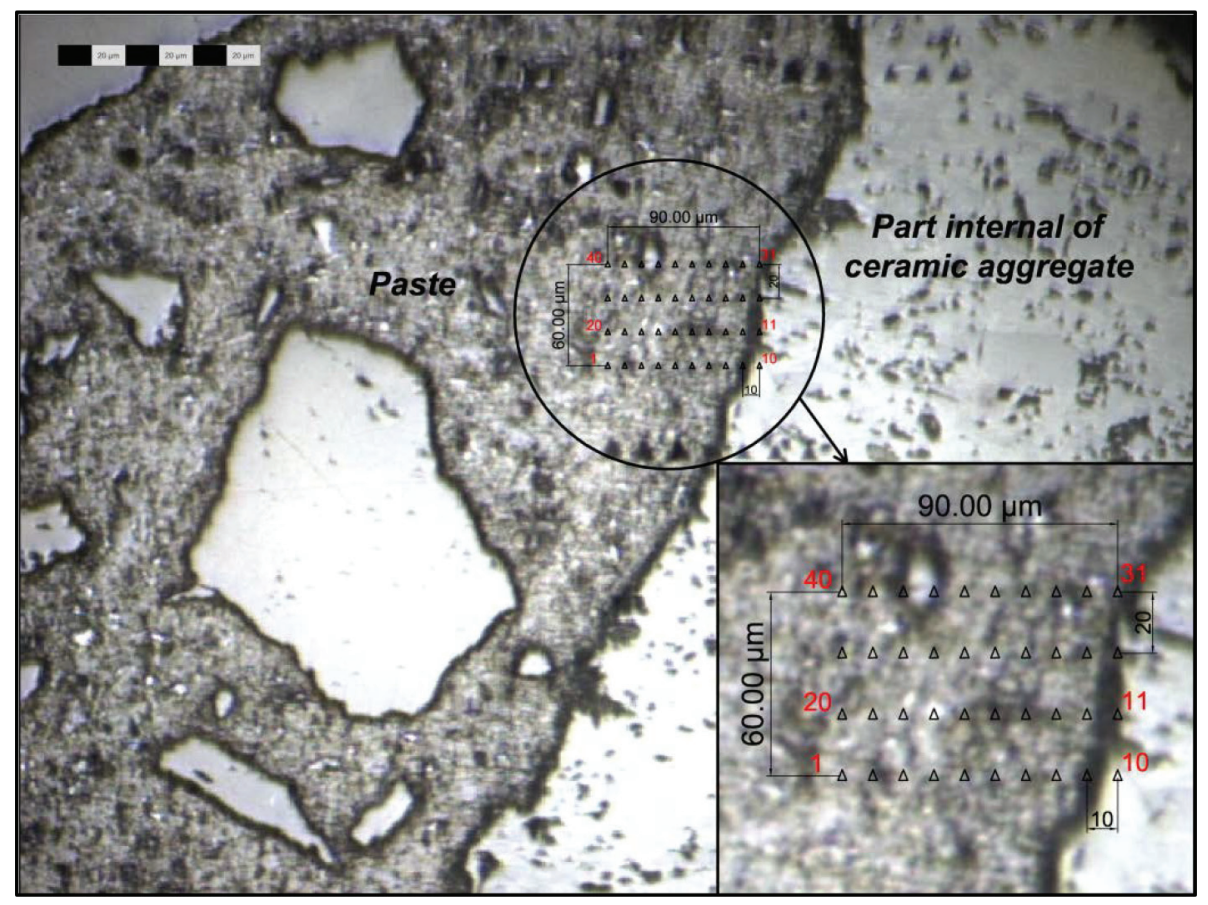

Fig. 4. BSE image of part internal of ceramic aggregate interfacial transition zone, where the dimension of the indented area is $90 \times 60 \mu \mathrm{m}$ with indent spacing of 10 and $20 \mu \mathrm{m}$ in $\mathrm{X}$ and $\mathrm{Y}$ direction respectively

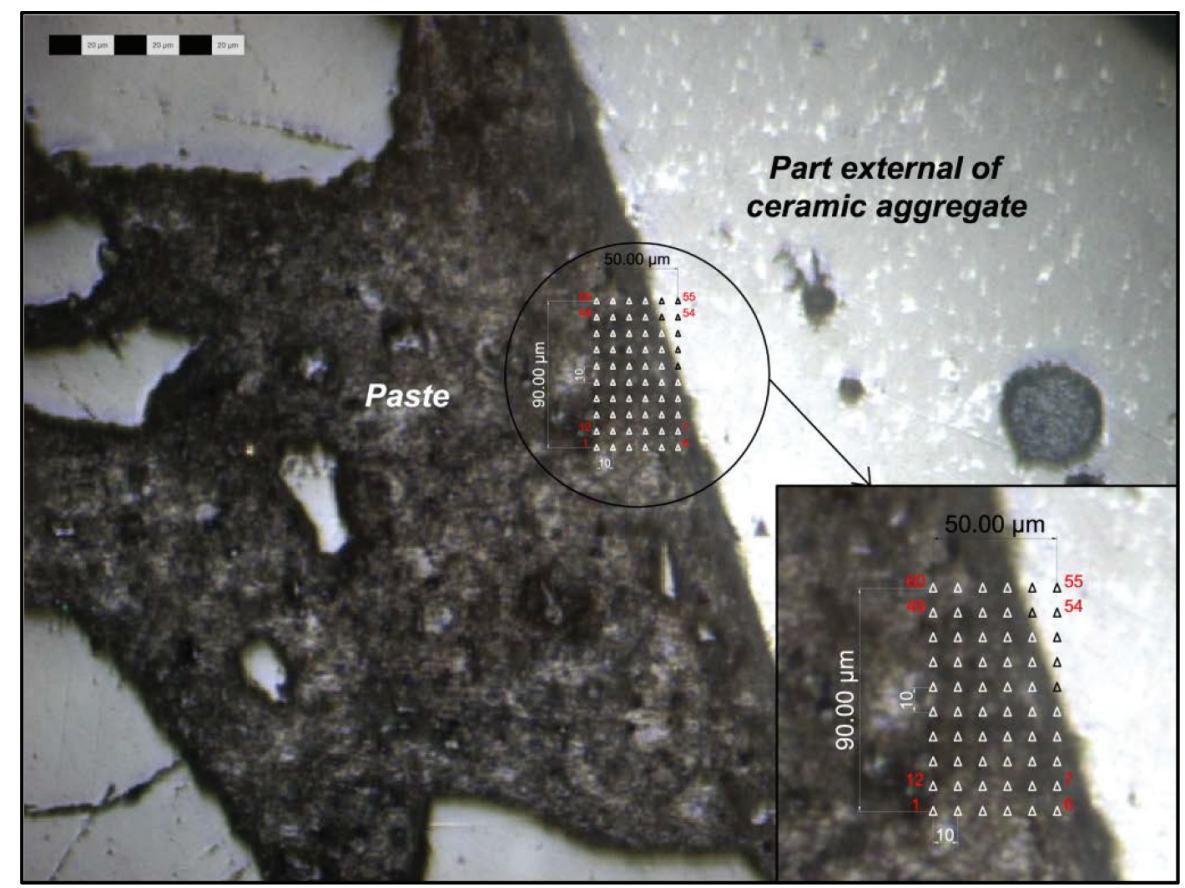

Fig. 5. BSE image of part external of ceramic aggregate interfacial transition zone, where the dimension of the indented area is $50 \times 90 \mu \mathrm{m}$ with an indent spacing of $10 \mu \mathrm{m}$ 
Table 4. Number of indentation test performed in each type of aggregate

\begin{tabular}{llccc}
\hline \multirow{2}{*}{ Type of aggregate } & \multicolumn{3}{c}{ Number of indentation tests } \\
\cline { 2 - 5 } & Internal part (matrix) & ITZ & Paste & Aggregate \\
\cline { 2 - 5 } Ceramic aggregate & 90 & 112 & 18 \\
\cline { 2 - 5 } & External part (glaze) & 104 & 80 & 13 \\
\hline \multirow{2}{*}{ Gravel } & 89 & 100 & 10 \\
\hline
\end{tabular}

face roughness, large voids or cracking. When such imperfections were detected, which was only rarely $(<2 \%$ of the total), the respective data were excluded in further data analysis. The total number of valid test points obtained and used is provided in Table 4, covering the various aggregates, ITZs and the bulk paste.

\section{Results and discussion}

\subsection{Characterization of the aggregates}

Figure 6 shows the results obtained of elastic modulus from aggregates. The natural aggregate have higher value than ceramic aggregate, as a consequences of its mineralogical composition (see point 2.1). This value is in accordance with the result obtained by other authors (Sakulich, Li 2011; Zhu et al. 2007) that they observe an elastic modulus of 100-120 GPa.

With respect to the ceramic aggregate, the internal part has a higher modulus than the external part. The different values obtained between natural aggregate and ceramic aggregate by elastic modulus are due to different mineralogy of these materials, because aluminosilicates have lesser value (80-90 GPa) than quartz.

\subsection{Characterization of the ITZ}

Table 5 shows the variations in the elastic modulus detected with nanoindentation at the ITZ studied (internal part/paste, external part/paste and natural aggregate/ paste) and the values of the standard deviation. Variations observed in the elastic modulus across the ITZ concurred with the findings reported in research papers on natural aggregate (Lutz et al. 1997; Sakulich, Li 2011; Zhu et al. 2004b). In the area closest to the surface

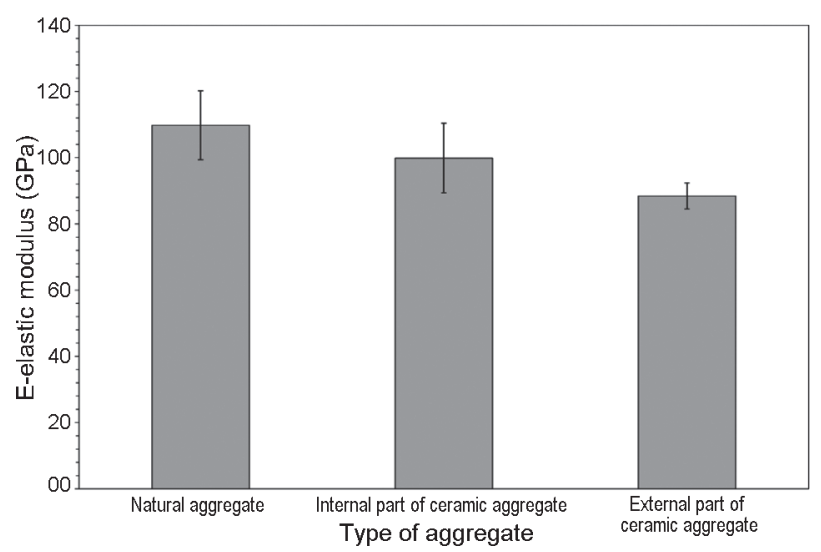

Fig. 6. Elastic modulus of coarse aggregates
$(5-15 \mu \mathrm{m})$, the modulus declined to a minimum value that ranged from 19.9 to $25.4 \mathrm{GPa}$. In this point $(x=15 \mu \mathrm{m})$ we can observe important differences in function of the type of aggregate-paste interface. It subsequently rose in the $15-30 \mu \mathrm{m}$ area and flattened at around $30-40 \mathrm{GPa}$ at distances of over $35 \mu \mathrm{m}$. The value recorded at the points adjacent to or at less than $10 \mu \mathrm{m}$ from the aggregate surface was impacted by proximity to the surface, an observation also reported by Zhu and Bartos (Zhu et al. 2004b). This is mainly because the affected surface area by the indentation could be 5-7 times greater than the indentation depth. Also, the interface observed in $2 \mathrm{D}$ may slightly differ from the real interface in $3 \mathrm{D}$, which could lead to a small error of the distance to the interface measured.

As regards the lowest of the minimum values observed $(19.9 \pm 2.7 \mathrm{GPa})$ was found for the natural aggregate/paste interface (Figure 8 ), followed by the value for the interface between the external (glazed) part of the recycled ceramic aggregate/paste $(23.7 \pm 2.5 \mathrm{GPa})$ and lastly the area between the internal part/paste $(25.4 \pm$ $2.5 \mathrm{GPa}$ ): i.e. the elastic modulus for the ceramic aggregate were 19.1 and $27.6 \%$ greater, respectively, than for the natural aggregate. These differences may be explained to the shape and chemical composition of the recycled ceramic aggregate. The ceramic materials (Sánchez de Rojas et al. 1993; Luxan et al. 1989; Mehta 1981; Uzal, Turanli 2003) have pozzolanic activity when they are in powder and this activity is smaller (Medina et al. 2012a, b) when they have coarse size. This research group has evaluated this activity with an accelerated chemical test that it is based on lime uptake by the material when it was cured in a saturated lime solution. The results obtained shown that this ceramic waste displayed acceptable pozzolanic activity, having been fixed more than $50 \%$ after 28 days. This value is similar to other ceramic materials (clay tile, bricks, etc.) but it's more active than fly ash at this age and it is less than silica fume.

The Figure 7 shows the points where we have analysed the value of C/S ratio from gel C-S-H of the different ITZs. The results obtained are shown in the Table 6 . You can observe that the $\mathrm{C} / \mathrm{S}$ ratios are similar and in accordance the interval values (1.2-2.3) established by Hewlett (1998) and Taylor (1997). These results indicate that the incorporation of ceramic aggregate doesn't present any negative effective in the formation of gel C-S-H. 

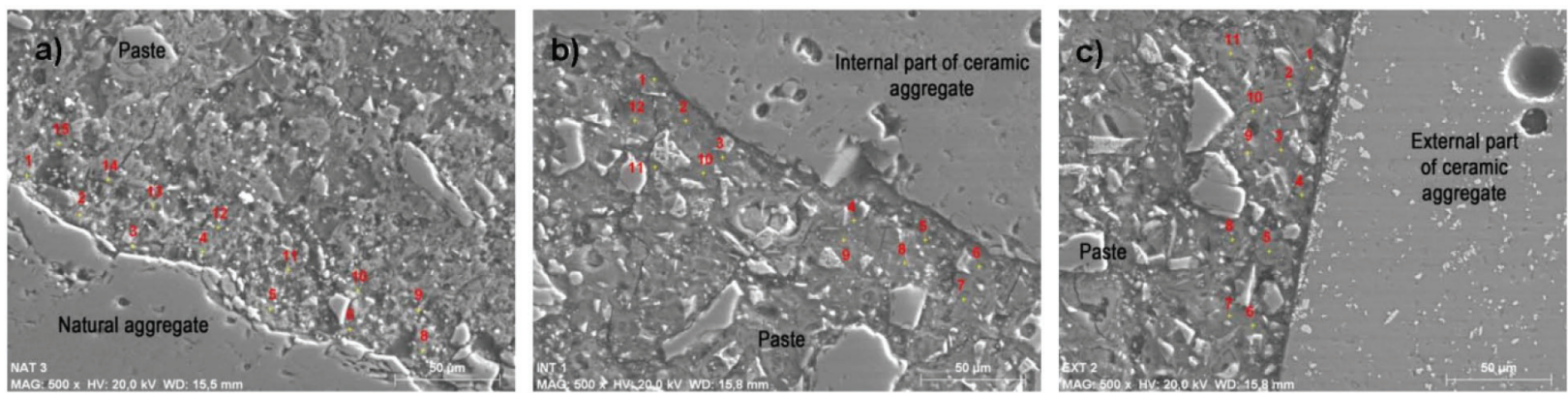

Fig. 7. BSE image of different ITZs (500X): a) Aggregate/paste; b) Internal part of ceramic aggregate/paste; c) External part of ceramic aggregate/paste

Table 5. Elastic modulus (GPa) vs distance from the aggregate surface by type of aggregate

\begin{tabular}{lccc}
\hline \multirow{2}{*}{$\begin{array}{l}\text { Distance from the } \\
\text { interface }(\mu \mathrm{m})\end{array}$} & \multicolumn{3}{c}{ Elastic modulus $(\mathrm{GPa})$} \\
\cline { 2 - 3 } & \multicolumn{2}{c}{ Ceramic aggregate } & Gravel \\
\cline { 2 - 3 } & Internal part (matrix) & External part (glaze) & \\
\hline 5 & $46.7 \pm 5.3{ }^{\text {a }}$ & $61.0 \pm 6.7$ & $70.0 \pm 5.9$ \\
\hline 10 & $31.0 \pm 3.7$ & $36.5 \pm 3.4$ & $37.3 \pm 1.6$ \\
\hline 15 & $\mathbf{2 5 . 4 \pm \mathbf { 2 . 5 }}$ & $\mathbf{2 3 . 7 \pm \mathbf { 2 . 5 }}$ & $\mathbf{1 9 . 9 \pm \mathbf { 2 . 7 }}$ \\
\hline 20 & $27.8 \pm 3.0$ & $24.8 \pm 2.6$ & $22.7 \pm 3.3$ \\
\hline 25 & $27.3 \pm 3.3$ & $25.8 \pm 2.5$ & $29.1 \pm 3.8$ \\
\hline 30 & $29.4 \pm 4.2$ & $29.9 \pm 3.2$ & $31.1 \pm 4.5$ \\
\hline 35 & $33.5 \pm 3.8$ & $32.6 \pm 3.0$ & $30.3 \pm 1.6$ \\
\hline 40 & $34.3 \pm 4.1$ & $35.4 \pm 2.6$ & $32.6 \pm 3.1$ \\
\hline 45 & $34.0 \pm 2.7$ & $33.3 \pm 3.5$ & $33.9 \pm 3.5$ \\
\hline 50 & $30.8 \pm 3.7$ & $31.9 \pm 2.2$ & $31.2 \pm 2.2$ \\
\hline 55 & $31.7 \pm 3.2$ & $39.4 \pm 3.5$ & $35.3 \pm 4.7$ \\
\hline 60 & $34.0 \pm 2.4$ & $37.8 \pm 3.4$ & $34.9 \pm 2.6$ \\
\hline 65 & $33.8 \pm 4.4$ & $34.2 \pm 2.6$ & $34.7 \pm 4.1$ \\
\hline 70 & $34.4 \pm 3.0$ & $36.4 \pm 3.2$ & $34.6 \pm 2.6$ \\
\hline
\end{tabular}

a The + represents one standard deviation

The elastic moduli were classified into two groups for comparison and assessment of the variations in the areas analysed (Fig. 8): one group was calculated for distances within the interface $(10 \mu \mathrm{m}<d<30 \mu \mathrm{m})$ and the other for distances in the paste $(35 \mu \mathrm{m}<d<70 \mu \mathrm{m})$. As the figure shows, the mean elastic modulus remained practically constant in the two areas (ITZ and paste) in concrete with both natural and recycled aggregate, an indication of similar behaviour. The mean $E$ value for the ITZ was found to be around $84 \%$ of $E$ value for the bulk paste for all the aggregate-paste systems studies. These findings are consistent with the results reported by Trtik and Bartos (1999) and Mondal et al. (2009), who observed that the elastic moduli at the interface ranged from 30 to $90 \%$ of the value in the paste, depending on the type of aggregate.

As Table 5 shows, the ITZ was 10-30 $\mu \mathrm{m}$ thickness in all cases, which concurred with the values observed by Zimbelmann (1985), Delagrave et al. (1997) and Trtik and Bartos (1999). Moreover, that value was smaller than both the normal thickness $10 \times 50 \mu \mathrm{m}$ found in natural aggregate/paste interfaces (Lee, Park 2008; Zheng et al. 2005), and the 30 to $60 \mu \mathrm{m}$ reported for recycled concrete aggregate/paste interfaces (Li et al. 2009; Poon et al. 2004). Such results constitute further evidence that the inclusion of this new type of recycled aggregate had no adverse effect on interfacial transition zone micro-properties. To some extent, it contributes to improve the ITZ properties, as the enhanced lowest $E$ value within the ITZ suggests.

\subsection{Engineering properties}

In light of the foregoing, three basic engineering properties (compressive strength, splitting tensile strength and modulus of elasticity) were analysed with a view to assessing the beneficial effect of recycled ceramic aggregate on the macro-properties of recycled concrete.

Table 7 clearly shows that the inclusion of recycled sanitary ware as aggregate improved the engineering properties of conventional concrete (Medina et al. 2011, 2012a, b). 
Table 6. Microanalysis of gel C-S-H on different ITZs

\begin{tabular}{lccc}
\hline Element & Natural aggregate/paste & $\begin{array}{c}\text { Internal part of ceramic } \\
\text { aggregate/paste }\end{array}$ & $\begin{array}{c}\text { External part of ceramic } \\
\text { aggregate/paste }\end{array}$ \\
\hline $\mathrm{O}$ & $34.06 \pm 0.30$ & $39.18 \pm 0.75$ & $39.23 \pm 0.45$ \\
\hline $\mathrm{Na}$ & $0.00 \pm 0.08$ & $0.11 \pm 0.15$ & $0.12 \pm 0.13$ \\
\hline $\mathrm{Mg}$ & $0.39 \pm 0.14$ & $2.49 \pm 1.30$ & $1.80 \pm 0.74$ \\
\hline $\mathrm{Al}$ & $2.44 \pm 0.17$ & $4.13 \pm 1.03$ & $3.40 \pm 0.84$ \\
\hline $\mathrm{Si}$ & $18.76 \pm 0.60$ & $16.00 \pm 1.75$ & $16.36 \pm 0.81$ \\
\hline $\mathrm{P}$ & $0.00 \pm 0.01$ & $0.19 \pm 0.16$ & $0.20 \pm 0.11$ \\
\hline $\mathrm{S}$ & $0.51 \pm 0.05$ & $0.67 \pm 0.40$ & $0.88 \pm 0.47$ \\
\hline $\mathrm{K}$ & $0.85 \pm 0.07$ & $0.32 \pm 0.17$ & $0.24 \pm 0.06$ \\
\hline $\mathrm{Ca}$ & $41.02 \pm 0.98$ & $34.92 \pm 3.27$ & $35.88 \pm 1.59$ \\
\hline $\mathrm{Ti}$ & $0.05 \pm 0.02$ & $0.19 \pm 0.15$ & $0.25 \pm 0.21$ \\
\hline $\mathrm{Fe}$ & $1.42 \pm 0.19$ & $1.78 \pm 0.53$ & $1.81 \pm 0.44$ \\
\hline $\mathrm{C} / \mathrm{S}$ & 2.18 & 2.18 & 2.19 \\
\hline
\end{tabular}

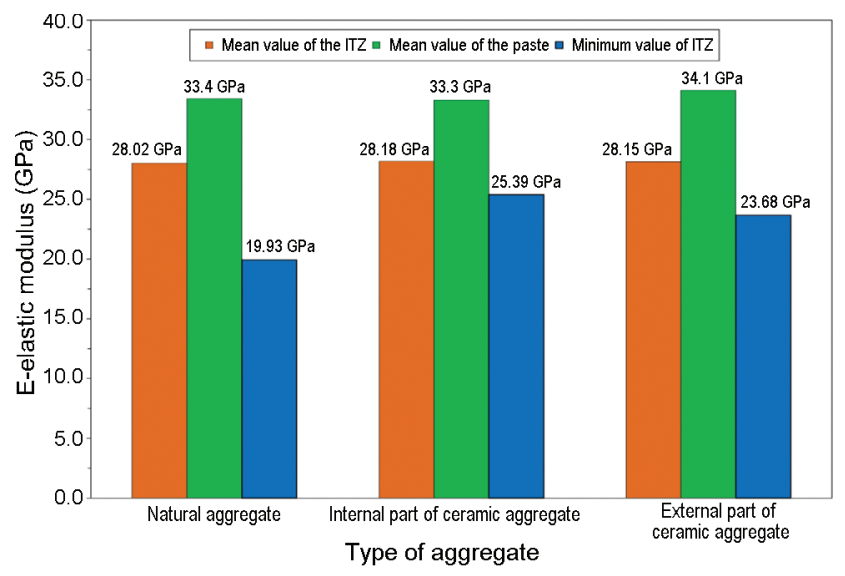

Fig. 8. Mean and minimum values of elastic modulus (GPa) in interfacial transition zone and mean value in paste

The greater compressive and splitting tensile strength in these new concretes (Medina et al. 2012b) can be attributed to the intrinsic properties of the ceramic aggregate (Medina et al. 2011) and the effect of the microproperties of interfacial transition zone on the mechanical behaviour (Holschemacher 2004). Note that the minimum elastic modulus for both the internal and external part of ceramic aggregate/paste interface was higher than for the natural aggregate/paste interface.

Splitting tensile strength rose more than the other parameters because this strength is closely related to the ease with which micro-cracks form (Akçaoğlu et al. 2004; Tasdemir et al. 1998) at the ITZ when the concrete is loaded. This increase was $19.70 \%$ higher in CC-20 and $25.65 \%$ in CC-25 than in the RC. The primary reason for the appearance of such micro-cracks is that the elastic modulus differs in paste and aggregate (Fig. 6); and that difference is greater between natural aggregate/paste than between recycled aggregate/paste.

The estimated value of the modulus of elasticity in concretes (Table 7) was observed to rise slightly with the
Table 7. Engineering properties of the 28-day concretes

\begin{tabular}{lccc}
\hline $\begin{array}{l}\text { Type of } \\
\text { concrete }\end{array}$ & $\begin{array}{c}\text { Compressive } \\
\text { strength (MPa) }\end{array}$ & $\begin{array}{c}\text { Tensile } \\
\text { strength } \\
(\mathrm{MPa})\end{array}$ & $\begin{array}{c}\text { Modulus of } \\
\text { elasticity } \\
(\mathrm{GPa})^{*}\end{array}$ \\
\hline $\mathrm{RC}$ & 35.87 & 2.69 & 30.1 \\
\hline $\mathrm{CC}-20$ & 38.53 & 3.22 & 30.6 \\
\hline CC-25 & 39.83 & 3.38 & 31.3 \\
\hline
\end{tabular}

*Calculated through an empirical formula suggest by ACI 318-08.

percentage of ceramic aggregate and was $1.7 \%$ higher in CC20 and 4.0\% higher in CC25 than in the reference concrete. This behaviour is closely related to the slightly higher elastic modulus found in the (internal and external) ceramic aggregate/paste interface than in the natural aggregate/paste interface. These findings are consistent with Lee and Park (2008).

\section{Conclusions}

A number of conclusions about the use of nanoindentation in the research of the interfacial transition zone between recycled ceramic aggregate/paste in recycled concrete can be drawn from this study:

1. The general distribution pattern of the elastic modulus in both recycled ceramic/paste and natural aggregate/paste interfacial zone is as expected, and similar to those reported previously.

2. The minimum value of the elastic modulus was greater in the ITZ between (internal and external part) ceramic aggregate/paste than in the natural aggregate/paste interface. This appears to correlate well with the improved tensile strength properties of the concrete containing such recycled aggregates.

3. The minimum $E$ value was found at around $15 \mu \mathrm{m}$ from the actual aggregate surface. There is, however, no significant difference in mean $\mathrm{E}$ value of 
the ITZ between the recycled ceramic aggregate/ paste and the natural aggregate/paste systems.

4. The thickness of the ITZ was found to be 10-30 $\mu \mathrm{m}$ for both the natural aggregate-paste and recycled aggregate-paste system, which is thinner than found for other types of recycled aggregates reported. The results also suggest that the ITZ is not adversely affected by the inclusion of recycled aggregate used in the study.

The findings of the present study confirm that nanoindentation is an indispensable tool for studying and assessing the effect of new materials (recycled aggregate) on the micro-mechanical properties of the interfacial transition zone (ITZ) and their impact on the macro properties of future recycled aggregate concretes.

\section{Acknowledgments}

This research has been made possible through funding from the Spanish Ministry for Science and Innovation's national project ref. BIA2010-21194-C03-01, "Recovery of ceramic C\&DW as a pozzolanic material and as recycled aggregate. Influence of pollutants. Optimization in recycling plants". Finally, we want to express our appreciation to the University of the West of Scotland (United Kingdom) for its collaboration in this research.

\section{References}

ACI Comittee 318-08: Building Code Requirements for Structural Concrete and Commentary. 2008. Detroit: American Concrete Institute. 471 p. (in English).

Akcaoglu, R.; Tokyay, M.; Celik, T. 2005. Assessing the ITZ microcracking via scanning electron microscope and its effect on the failure behavior of concrete, Cement and Concrete Research 35(2): 358-363. http://dx.doi.org/10.1016/j.cemconres.2004.05.042

Akçaoğlu, T.; Tokyay, M.; Çelik, T. 2004. Effect of coarse aggregate size and matrix quality on ITZ and failure behavior of concrete under uniaxial compression, Cement and Concrete Composites 26(6): 633-638. http://dx.doi.org/10.1016/S0958-9465(03)00092-1

ASTM E2546-07: Standard practice for instrumented indentation testing [online], [cited 24 May 2012]. American Society for Testing and Material International, West Conshohocken, PA. Available from Internet: www.astm.org

Bentur, A.; Alexander, M. G. 2000. A review of the work of the RILEM TC 159-ETC: Engineering of the interfacial transition zone in cementitious composites, Materials and Structures 33(226): 82-87.

http://dx.doi.org/10.1007/BF02484160

Comisión Permanente del Hormigón. 2008. Code on structural concrete -EHE 08. $1^{\text {st }}$ ed. Ministerio de Fomento. Madrid. 704 p. (in English).

Davydov, D.; Jirásek, M.; Kopecký, L. 2011. Critical aspects of nano-indentation technique in application to hardened cement paste, Cement and Concrete Research 41(1): 20-29. http://dx.doi.org/10.1016/j.cemconres.2010.09.001

Delagrave, A.; Bigas, J. P.; Ollivier, J. P.; Marchand, J.; Pigeon, M. 1997. Influence of the interfacial zone on the chloride diffusivity of mortars, Advanced Cement Based Materials 5(3-4): 86-92.

http://dx.doi.org/10.1016/S1065-7355(96)00008-9
Diamond, S.; Huang, J. D. 2001. The ITZ in concrete - a different view based on image analysis and SEM observations, Cement \& Concrete Composites 23(2-3): 179-188. http://dx.doi.org/10.1016/S0958-9465(00)00065-2

EN 197-1. Cement - Part 1: Composition, specifications and conformity criteria for common cements. European committee for standardization. Brussels, 2011. 40 p. (in English).

EN 12390-2. Testing hardened concrete - Part 2: Making and curing specimens for strength tests. European committee for standardization. Brussels, 2009a. 12 p.

EN 12620:2003+A1:2009. Aggregate for concrete. European committee for standardization. Brussels, 2009b. 58 p. (in English).

Fernández, M. O. 2007. Hormigón. Octava Edición Edition. Colegio de Ingenieros de Caminos, Canales y Puertos. Madrid. $666 \mathrm{p}$.

Hewlett, P. C. 1998. Lea's chemistry of cement and concrete. Fourth Edition. London. 1053 p.

Holschemacher, K. 2004. Hardened material properties of selfcompacting concrete, Journal of Civil Engineering and Management 10(4): 261-266. http://dx.doi.org/10.1080/13923730.2004.9636318

Hughes, J. J.; Trtik, P. 2004. Micro-mechanical properties of cement paste measured by depth-sensing nanoindentation: a preliminary correlation of physical properties with phase type, Materials Characterization 53(2-4): 223-231. http://dx.doi.org/10.1016/j.matchar.2004.08.014

Kavussi, A.; Nejad, F. M.; Modarres, A. 2011. Laboratory fatigue models for recycled mixes with pozzolanic cement and bitumen emulsion, Journal of Civil Engineering and Management 17(1): 98-107. http://dx.doi.org/10.3846/13923730.2011.553990

Lee, K. M.; Park, J. H. 2008. A numerical model for elastic modulus of concrete considering interfacial transition zone, Cement and Concrete Research 38(3): 396-402. http://dx.doi.org/10.1016/j.cemconres.2007.09.019

Lee, S. F.; He, J. Y.; Wang, X. H.; Zhang, Z. L.; Jacobsen, S. 2009. Study of Ph Curves on nanomechanical properties of steel fiber reinforced mortar, Nanotechnology in Construction 3, Proceedings: 281-286.

Li, J.; Xiao, H.; Zhou, Y. 2009. Influence of coating recycled aggregate surface with pozzolanic powder on properties of recycled aggregate concrete, Construction and Building Materials 23(3): 1287-1291. http://dx.doi.org/10.1016/j.conbuildmat.2008.07.019

Lutz, M. P.; Monteiro, P. J. M.; Zimmerman, R. W. 1997. Inhomogeneous interfacial transition zone model for the bulk modulus of mortar, Cement and Concrete Research 27(7): 1113-1122. http://dx.doi.org/10.1016/S0008-8846(97)00086-0

Luxan, M. P.; Sánchez de Rojas, M. I.; Frias, M. 1989. Investigations on the fly ash calcium hydroxide reactions, Cement and Concrete Research 19(1): 69-80. http://dx.doi.org/10.1016/0008-8846(89)90067-7

Mačiulaitis, R.; Vaičiene, M.; Žurauskiene, R. 2009. The effect of concrete composition and aggregates properties on performance of concrete, Journal of Civil Engineering and Management 15(3): 317-324. http://dx.doi.org/10.3846/1392-3730.2009.15.317-324

Medina, C.; Frías, M.; Sánchez de Rojas, M. I. 2012a. Microstructure and properties of recycled concretes using ceramic sanitary ware industry waste as coarse aggregate, Construction and Building Material 31: 112-118. http://dx.doi.org/10.1016/j.conbuildmat.2011.12.075

Medina, C.; Juan, A.; Frías, M.; Sánchez de Rojas, M. I.; Morán, J. M.; Guerra, M. I. 2011. Characterization of concrete made with recycled aggregate from ceramic sanitary ware, Materiales de Construcción 61(304): 533-546. http://dx.doi.org/10.3989/mc.2011.59710 
Medina, C.; Sánchez de Rojas, M. I.; Frías, M. 2012 b. Reuse of sanitary ceramic wastes as coarse aggregate in eco-efficient concretes, Cement and Concrete Composites 34(1): 48-54. http://dx.doi.org/10.1016/j.cemconcomp.2011.08.015

Mehta, P. K. 1981. Studies on blended portland cements containing santorin earth, Cement and Concrete Research 11(4): 507-518. http://dx.doi.org/10.1016/0008-8846(81)90080-6

Mondal, P.; Shah, S. P.; Marks, L. D. 2009. Nanomechanical Properties of interfacial transition zone in concrete, Nanotechnology in Construction 3, Proceedings: 315-320.

Mondal, P.; Surendra P. S.; Marks, L. 2007. A reliable technique to determine the local mechanical properties at the nanoscale for cementitious materials, Cement and Concrete Research 37(10): 1440-1444. http://dx.doi.org/10.1016/j.cemconres.2007.07.001

Monteiro, P. J. M.; Maso, J. C.; Ollivier, J. P. 1985. The aggregate - mortar interface, Cement and Concrete Research 15(6): 953-958.

http://dx.doi.org/10.1016/0008-8846(85)90084-5

Oliver, W. C.; Pharr, G. M. 2004. Measurement of hardness and elastic modulus by instrumented indentation: Advances in understanding and refinements to methodology, Journal of Materials Research 19(1): 3-20. http://dx.doi.org/10.1557/jmr.2004.19.1.3

Ollivier, J. P.; Maso. J. C.; Bourdette, B. 1995. Interfacial transition zone in concrete, Advanced Cement Based Materials 2(1): 30-38. http://dx.doi.org/10.1016/1065-7355(94)00021-5

Paulon, V. A.; Dal Molin, D.; Monteiro, P. J. M. 2004. Statistical analysis of the effect of mineral admixtures on the strength of the interfacial transition zone, Interface Science 12(4): 399-410. http://dx.doi.org/10.1023/B:INTS.0000042338.54460.02

Poon, C. S.; Shui, Z. H.; Lam, L. 2004. Effect of microstructure of ITZ on compressive strength of concrete prepared with recycled aggregates, Construction and Building Materials 18(6): 461-468. http://dx.doi.org/10.1016/j.conbuildmat.2004.03.005

Sakulich, A. R.; Victor C. Li. 2011. Nanoscale characterization of engineered cementitious composites (ECC), Cement and Concrete Research 41(2): 169-175. http://dx.doi.org/10.1016/j.cemconres.2010.11.001

Sánchez de Rojas, M. I. S.; Luxan, M. P.; Frias, M.; Garcia, N. 1993. The influence of different additions on portlandcement hydration heat, Cement and Concrete Research 23(1): 46-54. http://dx.doi.org/10.1016/0008-8846(93)90134-U

Sánchez de Rojas, M. I.; Frias, M.; Rivera, J.; Escorihuela, M. J.; Marin, F. P. 2001. Research about the pozzolanic activity of waste materials from calcined clay, Materiales De Construccion 51(261): 45-52. http://dx.doi.org/10.3989/mc.2001.v51.i261.379

Sánchez de Rojas, M. I.; Frías, M.; Rivera, J.; Marín, F. P. 2003. Waste products from prefabricated ceramic materials as pozzolanic addition, in $11^{\text {th }}$ International Congress on the Chemistry of Cement, 11-16 May 2003 Durban, South África.

Sánchez de Rojas, M. I.; Marin, F.; Rivera, J.; Frias, M. 2006. Morphology and properties in blended cements with ceramic wastes as a pozzolanic material, Journal of the American Ceramic Society 89(12): 3701-3705. http://dx.doi.org/10.1111/j.1551-2916.2006.01279.x

Sánchez de Rojas, M. I.; Marin, F. P.; Frias, M.; Rivera, J. 2007. Properties and performances of concrete tiles containing waste fired clay materials, Journal of the American Ceramic Society 90(11): 3559-3565. http://dx.doi.org/10.1111/j.1551-2916.2007.01944.x
Shen, L.-Y.; Hao, J. L.; Tam, V. W.-Y.; Yao, H. 2007. A checklist for assessing sustainability performance of construction projects, Journal of Civil Engineering and Management 13(4): 273-281.

Sorelli, L.; Constantinides, G.; Ulm, F.-J.; Toutlemonde, F. 2008. The nano-mechanical signature of ultra high performance concrete by statistical nanoindentation techniques, Cement and Concrete Research 38(12): 1447-1456. http://dx.doi.org/10.1016/j.cemconres.2008.09.002

Stark, J. 2011. Recent advances in the field of cement hydration and microstructure analysis, Cement and Concrete Research 41(7): 666-678. http://dx.doi.org/10.1016/j.cemconres.2011.03.028

Tasdemir, M. A.; Tasdemir, C.; Akyuz, S.; Jefferson, A. D.; Lydon, F. D.; Barr, B. I. G. 1998. Evaluation of strains at peak stresses in concrete: a three-phase composite model approach, Cement \& Concrete Composites 20(4): 301318. http://dx.doi.org/10.1016/S0958-9465(98)00012-2

Taylor, H. F. W. 1997. Cement. 2nd ed. London: Thomas Telford Publishing. $459 \mathrm{p}$.

Trtik, P.; Bartos, P. J. M. 1999. Micromechanical properties of cementitious composites, Materials and Structures 32(219): 388-393. http://dx.doi.org/10.1007/BF02479632

Uzal, B.; Turanli, L. 2003. Studies on blended cements containing a high volume of natural pozzolans, Cement and Concrete Research 33(11): 1777-1781. http://dx.doi.org/10.1016/S0008-8846(03)00173-X

van Breugel, K.; Koenders, E. A. B.; Guang, Y.; Lura, P. 2004. Modelling of transport phenomena at cement matrix-aggregate interfaces, Interface Science 12(4): 423-431. http://dx.doi.org/10.1023/B:INTS.0000042340.29735.92

Velez, K.; Maximilien, S.; Damidot, D.; Fantozzi, G.; Sorrentino, F. 2001. Determination by nanoindentation of elastic modulus and hardness of pure constituents of Portland cement clinker, Cement and Concrete Research 31(4): 555-561. http://dx.doi.org/10.1016/S0008-8846(00)00505-6

Wang, X.H.; Jacobsen, S.; He, J. Y.; Zhang, Z. L.; Lee, S. F.; Lein, H. L. 2009. Application of nanoindentation testing to study of the interfacial transition zone in steel fiber reinforced mortar, Cement and Concrete Research 39(8): 701-715. http://dx.doi.org/10.1016/j.cemconres.2009.05.002

Zheng, J. J.; Li, C. Q.; Zhou, X. Z. 2005. Thickness of interfacial transition zone and cement content profiles around aggregates, Magazine of Concrete Research 57(7): 397406. http://dx.doi.org/10.1680/macr.2005.57.7.397

Zhu, W.; Bartos, P. J. M. 1997. Assessment of interfacial microstructure and bond properties in aged GRC using a novel microindentation method, Cement and Concrete Research 27(11): 1701-1711. http://dx.doi.org/10.1016/S0008-8846(97)00155-5

Zhu, W.; Bartos P. J. M.; Porro, A. 2004a. Application of nanotechnology in construction - summary of a state-of-the-art report, Materials and Structures 37(273): 649-658. http://dx.doi.org/10.1617/14234

Zhu, W.; Hughes, J. J.; Bicanic, N.; Pearce, C. J. 2007. Nanoindentation mapping of mechanical properties of cement paste and natural rocks, Materials Characterization 58(11-12): 1189-1198.

http://dx.doi.org/10.1016/j.matchar.2007.05.018

Zhu, W.; Sonebi, M.; Bartos, P. J. M. 2004b. Bond and interfacial properties of reinforcement in self-compacting concrete, Materials and Structures 37(271): 442-448. http://dx.doi.org/10.1617/14012

Zhu, W.; Bartos, P. J. M. 2000. Application of depth-sensing microindentation testing to study of interfacial transition zone in reinforced concrete, Cement and Concrete Research 30(8): 1299-1304. http://dx.doi.org/10.1016/S0008-8846(00)00322-7 
Zhu, W.; Bartos, P. J. M. 2005. Microstructure and properties of interfacial transition zone in SCC, in $1^{\text {st }}$ International Symposium on Design, Performance and Use of Self-Consolidating Concrete. Changsha, Peoples Republic of China.
Zimbelmann, R. 1985. A contribution to the problem cement aggregate bond, Cement and Concrete Research 15(5): 801-808. http://dx.doi.org/10.1016/0008-8846(85)90146-2

César MEDINA. Post-doctorate Researcher in Eduardo Torroja Institute for Construction Sciences, Spanish National Research Council, Spain. Research interests include study of ceramic wastes and construction and demolition wastes for the manufacture of new cements, mortars and concretes, and the evaluation of leaching in construction materials.

Wenzhong ZHU. Lecturer in Civil Engineering, School of Engineering, University of the West of Scotland. Research interests include micromechanical characterization of materials, nanotechnology in construction materials, self-compacting concrete and wastes utilization/recycling in construction.

Torsten HOWIND. Research Associate in School of Engineering at the University of the West of Scotland, United Kingdom. Research interests include Micromechanical characterization of cementitious materials, bacterially mediated decay of concrete structure (especially biogenic sulphide corrosion), recycling in construction.

María Isabel SÁNCHEZ DE ROJAS. Scientific Researcher in Eduardo Torroja Institute for Construction Sciences, Spanish National Research Council, Spain. Research interests include valorisation of industrial by-products and wastes as pozzolanic additions for the manufacture of cements and concretes, from the scientific, technical and environmental viewpoint, microstructure, new cementing matrices, durability, expansive compounds, allergenic components (soluble chromium, ...).

Moisés FRÍAS. Scientific Researcher in Eduardo Torroja Institute for Construction Sciences, Spanish National Research Council, Spain. Research interests include evaluation of by-products and industrial wastes for use in the cement industry. 